Prepared for the U.S. Department of Energy

under Contract DE-AC05-76RL01830

\title{
Explicitly Accounting for Protected Lands within the GCAM 3.0
}

\begin{abstract}
JJ Dooley
Y Zhou
\end{abstract}

May 2012

Pacific Northwest

NATIONAL LABORATORY

Proudly Operated by Battelle Since 1965 


\title{
DISCLAIMER
}

This report was prepared as an account of work sponsored by an agency of the United States Government. Neither the United States Government nor any agency thereof, nor Battelle Memorial Institute, nor any of their employees, makes any warranty, express or implied, or assumes any legal liability or responsibility for the accuracy, completeness, or usefulness of any information, apparatus, product, or process disclosed, or represents that its use would not infringe privately owned rights. Reference herein to any specific commercial product, process, or service by trade name, trademark, manufacturer, or otherwise does not necessarily constitute or imply its endorsement, recommendation, or favoring by the United States Government or any agency thereof, or Battelle Memorial Institute. The views and opinions of authors expressed herein do not necessarily state or reflect those of the United States Government or any agency thereof.

\author{
PACIFIC NORTHWEST NATIONAL LABORATORY \\ operated by \\ BATTELLE \\ for the \\ UNITED STATES DEPARTMENT OF ENERGY \\ under Contract DE-AC05-76RL01830
}

Printed in the United States of America
Available to DOE and DOE contractors from the Office of Scientific and Technical Information,
P.O. Box 62, Oak Ridge, TN 37831-0062;
ph: (865) 576-8401
fax: $(865)$ 576-5728
email: reports@adonis.osti.gov

\begin{abstract}
Available to the public from the National Technical Information Service, U.S. Department of Commerce, 5285 Port Royal Rd., Springfield, VA 22161 ph: (800) 553-6847 fax: $(703) 605-6900$ email: orders@ntis.fedworld.gov online ordering: http://www.ntis.gov/ordering.htm
\end{abstract}

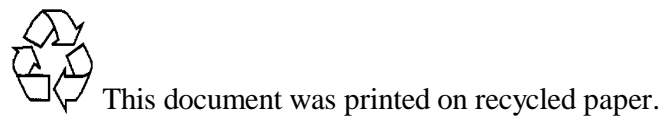


PNNL-21253

\section{Explicitly Accounting for Protected Lands within the GCAM 3.0}

JJ Dooley

Y Zhou

May 2012

Prepared for the U.S. Department of Energy under Contract DE-AC05-76RL01830

Pacific Northwest National Laboratory

Richland, Washington 99352 


\begin{abstract}
The Global Change Assessment Model Version 3.0 defines three different levels of "Protected Lands" within the agricultural and landuse component. These three different scenarios effectively cordon off 3.2\% (5.0 million $\left.\mathrm{km}^{2}\right)$ of the Earth's lands in the de minimus Protected Land Scenario, 4.9\% (7.2 million $\mathrm{km}^{2}$ ) in the Core Protected Land Scenario, and 8.4\% (11.8 million $\mathrm{km}^{2}$ ) in the Expanded Protected Land Scenario. None of these scenarios represents the "right" level of Protected Lands for the planet today or tomorrow. Rather, the goal is to create a range of scenarios that can be used in modeling demands for agricultural land for food and bioenergy crops, responses to climate change and the impact those would have on managed and unmanaged lands. These scenarios harness the wealth of information in the United Nations Environment Programme World Conservation Monitoring Centre's World Database on Protected Areas and its categories of explicit degrees of protection.
\end{abstract}

Keywords: Global Change Assessment Model Version 3.0, GCAM 3.0; Protected Lands; agriculture; bioenergy; landuse modeling; climate change; integrated assessment. 


\section{Executive Summary}

The Global Change Assessment Model Version 3.0 defines three different levels of "Protected Lands" within the agricultural and landuse component. This report articulates the rationale or "storyline" that underlies these three Protected Lands scenarios. These three scenarios are built upon data contained in the United Nations Environment Programme World Conservation Monitoring Centre's World Database on Protected Areas (WDPA), the only global dataset describing lands that are being protected (i.e., conserved) for various purposes and with varying levels of legally enforced protection. The incorporation of these three Protected Land Scenarios within GCAM 3.0 will allow us to begin answering the question as to the extent to which large-scale changes in landuse are consistent with the preservation of protected lands.

GCAM de minimus Protected Lands Scenario -- This scenario provides strict protection for the smallest amount of lands of the three GCAM 3.0 Protected Lands scenarios. Approximately $3.2 \%$ of lands are effectively off-limits. The lands in the de miniums Protected Land Scenario total 5.0 million $\mathrm{km}^{2}$. The defining feature of these protected lands is that they are are meant to be "wild" or "natural" areas, i.e., visited and enjoyed by humans but left in their natural state (i.e., no permanent settlements in many of these areas, no agricultural activities, no logging or mining). The land categories that are contained within this scenario include International Union for Conservation of Nature (IUCN) Categories Ia, Ib, II, and III. The scenario also includes lands that have been designated as World Heritage Sites, Ramsar Wetlands of International Importance, and United Nations Educational, Scientific and Cultural Organization (UNESCO) Man-Biosphere Programme lands if those lands are not already covered under IUCN Ia, Ib, II, and III.

GCAM Core Protected Lands Scenario --This intermediate scenario encompasses all the lands covered in the GCAM de minimus Protected Lands Scenario and also lands included in IUCN Category IV. The addition of Category IV lands brings the total amount of land under protection to 7.2 million $\mathrm{km}^{2}$ or just slightly more than $4.9 \%$ of the Earth's lands. Within the broader conservation community, ICUN Category IV lands represent a transition from "wild" to "managed lands." These additional lands are mostly wild but they also have significant human interventions. Examples of Category IV Protected Lands would include many of the national and state parks as well as national and state level wildlife reserves/refuges found in most nations.

GCAM Expanded Protected Lands Scenario --This scenario builds upon the previous two by adding in IUCN Category V and VI lands. The addition of Category V and VI lands brings the total amount of land under protection to 11.8 million $\mathrm{km}^{2}$ or just slightly more than $8.4 \%$ of the Earth's lands. Active human intervention in Category V and VI landscapes is an essential feature of these lands. The degree of human intervention in these lands has led some in the broad international conservation movement to argue that Category V and Category VI lands should not 
be included within the WDPA, as they are less deserving of conservation efforts than for example the more pristine Category Ia lands. Examples of IUCN Category V and VI lands would include habitats for various flora and fauna and forests where some amount of logging is allowed.

None of these scenarios represents the "right" level of Protected Lands for the planet today or tomorrow. What is the "right" level is a highly context specific and normative question. Rather, the goal is to create a range of scenarios that can be used in modeling demands for agricultural land for food and bioenergy crops, responses to climate change and the impact those would have on managed and unmanaged lands. These scenarios can be used in modeling human responses to climate change and the impact those responses would have on managed and unmanaged lands. They harness the wealth of information in the WDPA and the explicit degrees of protection afforded the lands covered. In terms of the GCAM Integrated Assessment Model, one could interpret these three Protected Land Scenarios as a proxy variable implying differing degrees of future fungibility between land types (e.g., a Category 1a land will always be protected but a Category VI land might lose its protected status if society thought that the intensive use of that land served a higher purpose in the future). 


\section{Table of Contents}

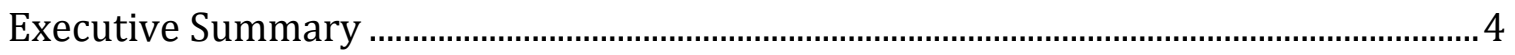

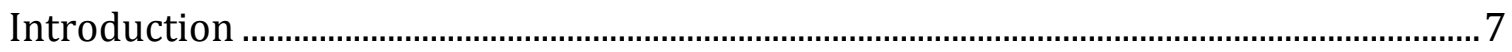

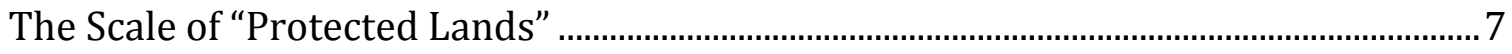

IUCN Categories Allow for the Meaningful Disaggregation of Protected Lands............ 9

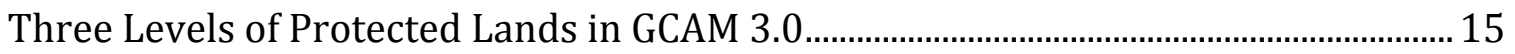

GCAM de minimus Protected Lands Scenario..................................................................... 16

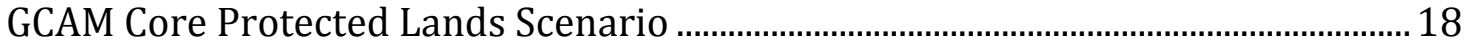

GCAM Expanded Protected Lands Scenario ................................................................... 19

Mapping Protected Land Scenarios to GCAM3.0’s AEZ Structure................................... 22

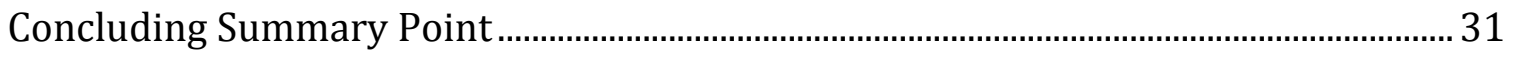

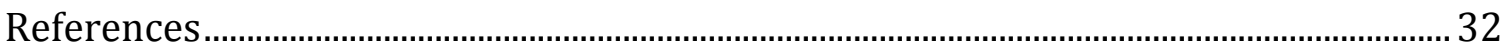




\section{Introduction}

As the Global Change Assessment Model Version 3.0 (hereafter, GCAM 3.0) continues to have a more geographically explicit and detailed representation of agriculture-landuse processes (Wise and Calvin, 2011), the questions being asked of this research tool are also becoming more specific. In particular, questions arise about potential conflicts between "natural areas" and managed lands in climate mitigation scenarios that envision large-scale landuse changes for large-scale deployment of bioenergy production (see for example, Luckow et al., 2010) or the preservation of terrestrial carbon stocks by avoiding deforestation (see for example, Wise et al., 2009). A next logical question arises as to what specific kinds of lands are being modified in these scenarios. In particular, questions have been raised about the extent to which scenarios like these are consistent with the expansion or at the very least preservation of protected lands such as national parks, critical wetlands, and biodiversity "hotspots."

This paper will describe how the rather amorphous term "protected lands" will be defined within GCAM 3.0 and how these lands are accounted for within GCAM. Early analyses will then begin to answer the question as to the extent to which large-scale changes in landuse are consistent with the preservation of protected lands.

\section{The Scale of "Protected Lands"}

The GCAM uses United Nations Environment Programme World Conservation Monitoring Centre's World Database on Protected Areas (WDPA) as its primary source of information about currently protected lands. The WDPA database is the internationally recognized standard for documenting protected lands - "the only global database of marine and terrestrial protected areas, comprising GIS spatial data and attribute data, in existence" (UNEP-WCMC, 2010). ${ }^{1}$ A large body of literature has documented shortcomings with this database (Bishop et al., 2004; Chape et al., 2003; Kapila, 2004; Richards and Parsons, 2004), and some of these shortcomings will be discussed here in terms of how the data is incorporated within GCAM. Despite the shortcomings, no comparable dataset spans the entire globe and describes protected lands at this level of detail. Therefore, GCAM utilizes the data contained in the WDPA.

As of early 2012, the WDPA database contained 160,365 records that describe terrestrial and marine "protected areas" (IUCN and UNEP-WCMC, 2012b). In total, these protected areas account for 24.4 million $\mathrm{km}^{2}$ of the Earth's surface with the vast majority $\left(153,414\right.$ areas) of protected areas being lands (18.3 million $\left.\mathrm{km}^{2}\right)$ with

\footnotetext{
${ }^{1}$ Philips (2004; 2008) and Bishop et. al., (2004) provide comprehensive histories international efforts to document "protected lands" and in particular the series of events in the $20^{\text {th }}$ century that led to the development of the WDPA and the evolution of the specific IUCN Protected Land Categories used within the WDPA.
} 
the remainder $\left(6,967\right.$ areas) being protected marine areas $\left(8.1\right.$ million $\left.\mathrm{km}^{2}\right)$ (IUCN and UNEP-WCMC, 2012a).

Figure 1 shows the growth in global protected lands in terms of the total area and in terms of the number of protected sites from 1911 to the present day. Figure 1

clearly shows that protected lands grew explosively, beginning at the end of the $20^{\text {th }}$ century. Fully half of the Protected Lands (both in terms of area and the number of locations) that currently exist were not formally declared to be protected lands until the early 1990s. Less than 10\% of today's protected lands (again both in terms of area and the number of locations) were designated as such before the mid 1960s.

What does having 18.3 million $\mathrm{km}^{2}$ of protected lands mean? It is equivalent to approximately $11 \%$ of all the land surface area on the planet, or nearly four-and-ahalf times ${ }^{2}$ larger than the total amount of urban areas. ${ }^{3}$ But what does it mean that $11 \%$ of all the land on the planet is listed in the WDPA database as protected lands? Is this land off-limits to all human activity in the present day and into the future? The answer is a resounding "no."

${ }^{2}$ CIESIN (CIESIN, 2005) reports that 3,506,830 $\mathrm{km}^{2}$ of the Earth's lands are urbanized. This is equal to $2.4 \%$ of the Earth's lands surface (inclusive of Antarctica and Greenland, which are large land masses that are largely uninhabited). If Antarctica and Greenland are excluded and one only calculates the percent of land urbanized using the land area of inhabited continents then the value for the percent of the earth that is urbanized is $2.68 \%$, which is the value reported by CIESIN (CIESIN, 2005)

${ }^{3}$ As will be explained below, the WDPA database contains minute portions of Antarctica and Greenland in its database. However here we will include Antarctica and Greenland as part of the Earth's lands but we will continue to rely on the WDPA to identify specific areas within these regions that are "Protected." If one excludes Antarctica and Greenland from their accounting of lands as the WDPA does, the comparable figure would be $13 \%$ of the Earth's lands are "protected lands." 


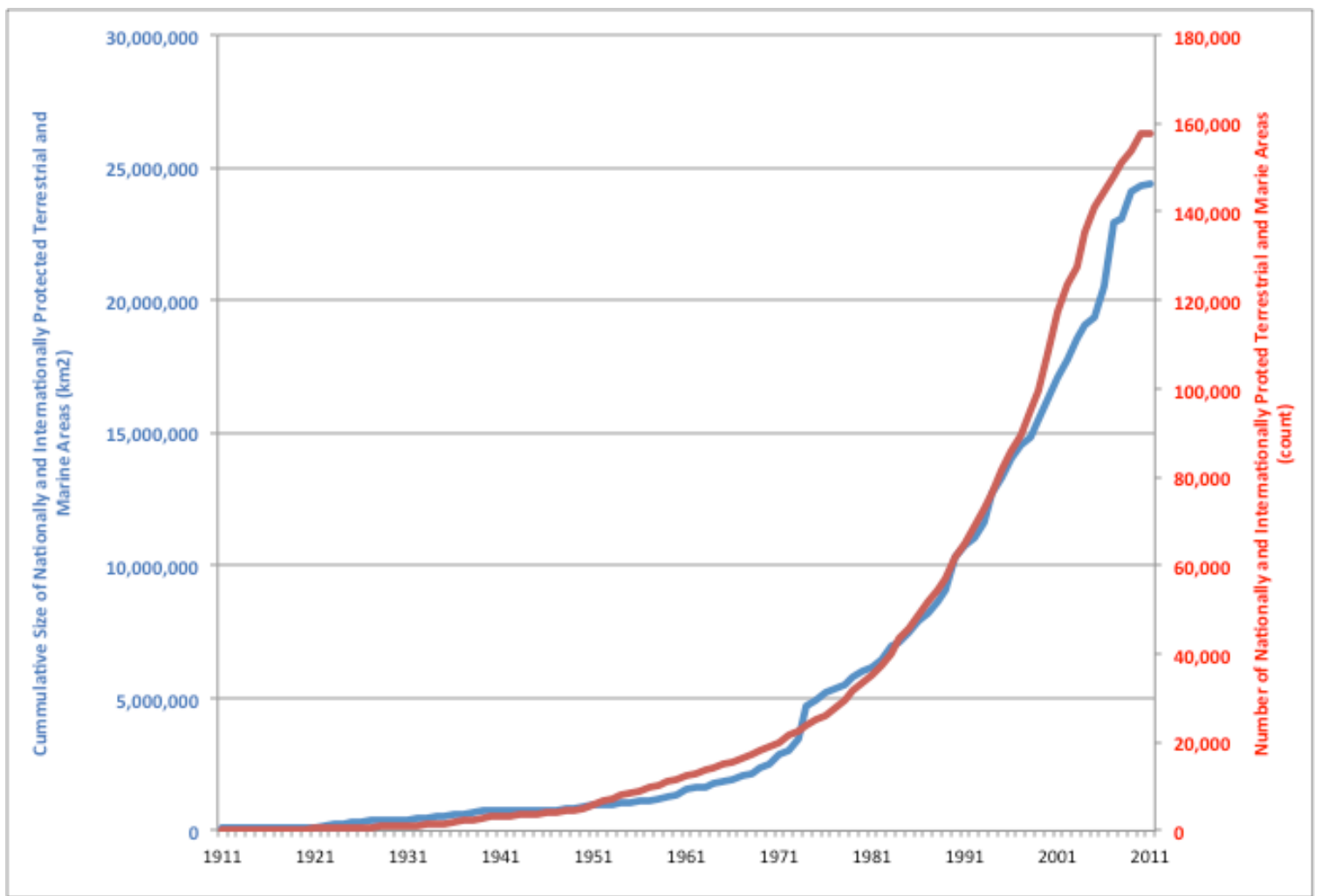

Figure 1: Growth in Global Protected Lands (millions of $\mathrm{km}^{2}$, left hand scale) and Number of Protected Areas (right hand scale) over the period 1911-2011 (IUCN and UNEP-WCMC, 2012a, b)

\section{IUCN Categories Allow for the Meaningful Disaggregation of Protected Lands}

A key benefit of the WDPA database is that all protected lands are assigned to one of seven categories of protection. These categories are called International Union for Conservation of Nature (IUCN) Categories, and this paper utilizes the IUCN's standard terminology when describing these lands. As can be seen from Figure 2, these IUCN categories explicitly are designed to reflect "a gradation of human intervention" that ranges from the strictest protections from human intervention to significant human intervention and modification of the protected lands (Phillips, 2004). In referring to the protected lands that lie at the least protected end of this spectrum the IUCN (1998) in the 1998 official report for the United Nations, 1997 United Nations List of Protected Areas, commented "a few indeed are no more than paper parks." 
For the remainder of this report, the focus will be solely on terrestrial protected areas as GCAM 3.0 does not model large-scale marine aquaculture or other large-scale anthropogenic uses of marine systems (Kyle et al., 2011; Wise and Calvin, 2011). GCAM 3.0 does - of course - include a representation of the role that the oceans play in larger climate dynamics (see for example, Thomson et al., 2011).

The IUCN category to which a particular parcel of land is assigned is largely determined by the entity ${ }^{4,5}$ that is putting forth that land as one that should be documented in the WDPA database. These IUCN categories are not binding and do not carry the force of law. Rather they are meant to be descriptive and aspirational as opposed to being proscriptive. As noted by Dudley and Stolton (2008), "Assignment to a category is not a comment on management effectiveness. This distinction is often overlooked. For instance, where category II areas are poorly managed, there is a temptation to re-classify them as category $\mathrm{V}$ areas. This is not the intent of the IUCN guidelines, which categorize by management objective."

\footnotetext{
${ }^{4}$ For the most restricted IUCN categories, the nominating entity is most likely a national government or an international body like the United Nations. However, this is by no means a prerequisite. For example, there are 11 Private Nature Reserves in Argentina that are categorized under IUCN 1a(IUCN and UNEP-WCMC, 2010). As noted by Dudley and Stolton (2008), "As the [IUCN Category] system is based on management objective, it is essentially neutral about the managing agency or landowner. More particularly, there is no presumption that any category will be owned or managed by the State."

${ }^{5}$ Party (2008) demonstrates that World Heritage Sites can be found in all of the IUCN Categories from Ia to VI.
} 
For the purposes of modeling landuse changes such as the expansion of forests or the establishment of bioenergy crop plantations in the GCAM 3.0, it is necessary to deal with the WDPA data in a much more disaggregated manner. In bringing these WDPA data into the GCAM 3.0, we will assume - and this report will document in detail - that virtually all changes in landuse from agriculture, forestry to energy production is inconsistent with lands covered by the IUCN " $1 \mathrm{a}$ " and " $1 \mathrm{~b}$ " categories. However, as will be discussed in more detail below, agriculture, forestry and even some levels of energy production may be consistent with lands protected in Category V.

\author{
IUCN Protected \\ Land Category
}

Unprotected

Landscapes
Ia/Ib, II, III IV V/VI

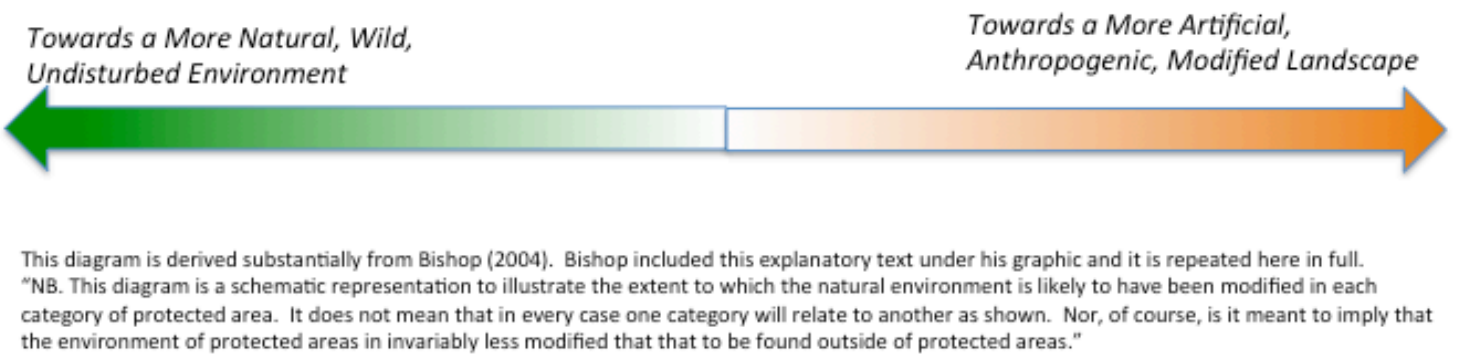

Figure 2 Schematic showing the varying levels of human intervention / modification across protected land categories (adapted from (Phillips, 2004))

Figure 3 shows the total amount of land in each of these IUCN categories for 2010 while Figure 4 shows the corresponding number of sites for these protected lands (IUCN and UNEP-WCMC, 2010).

Table 1 lists the IUCN categories as well as each category's official name and definition along with brief explanatory notes to help flesh out the differences between these categories. 


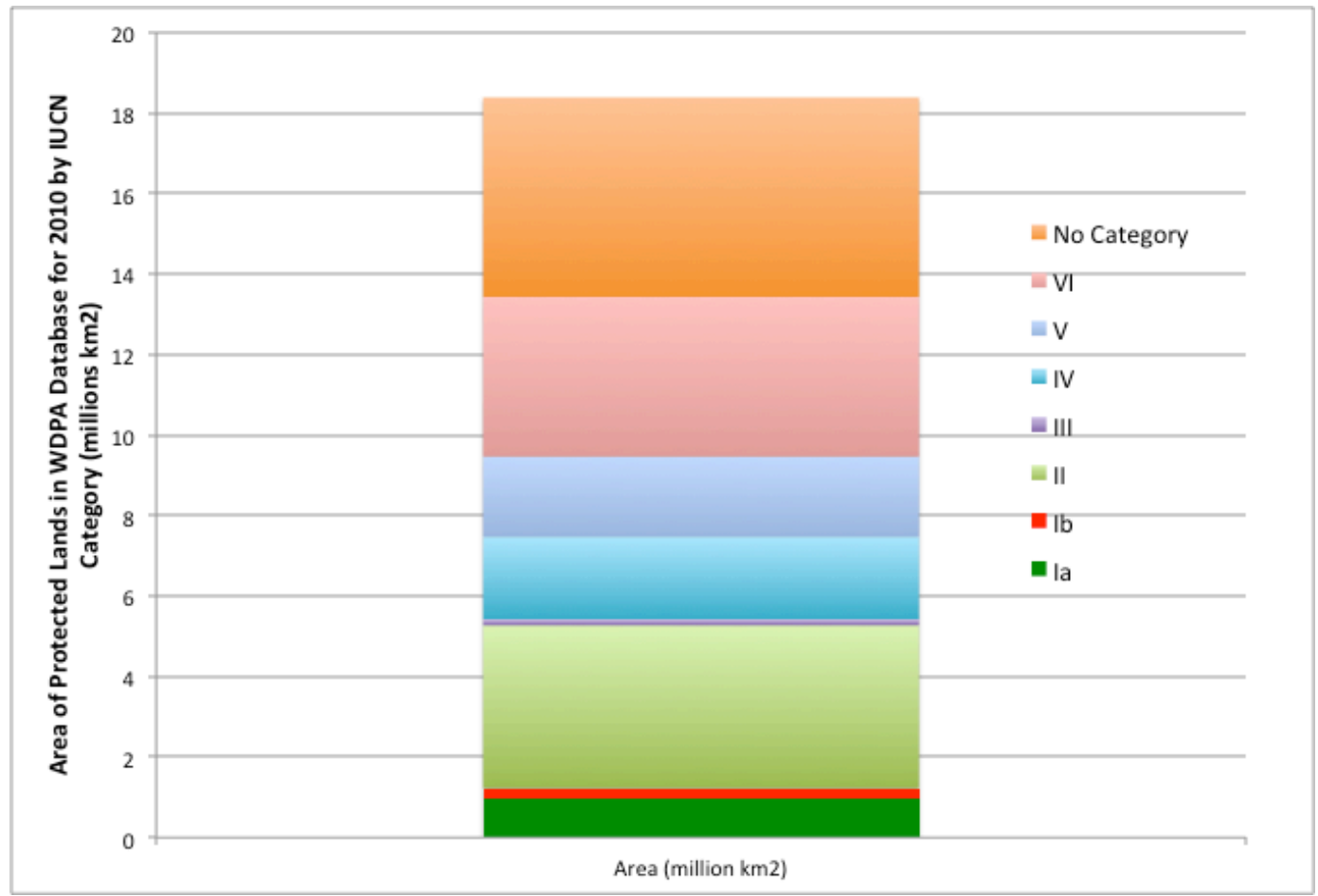

Figure 3 Area (millions of $\mathrm{km}^{2}$ ) of Land that is Protected disaggregated by IUCN Category for 2010 (IUCN and UNEP-WCMC, 2010)

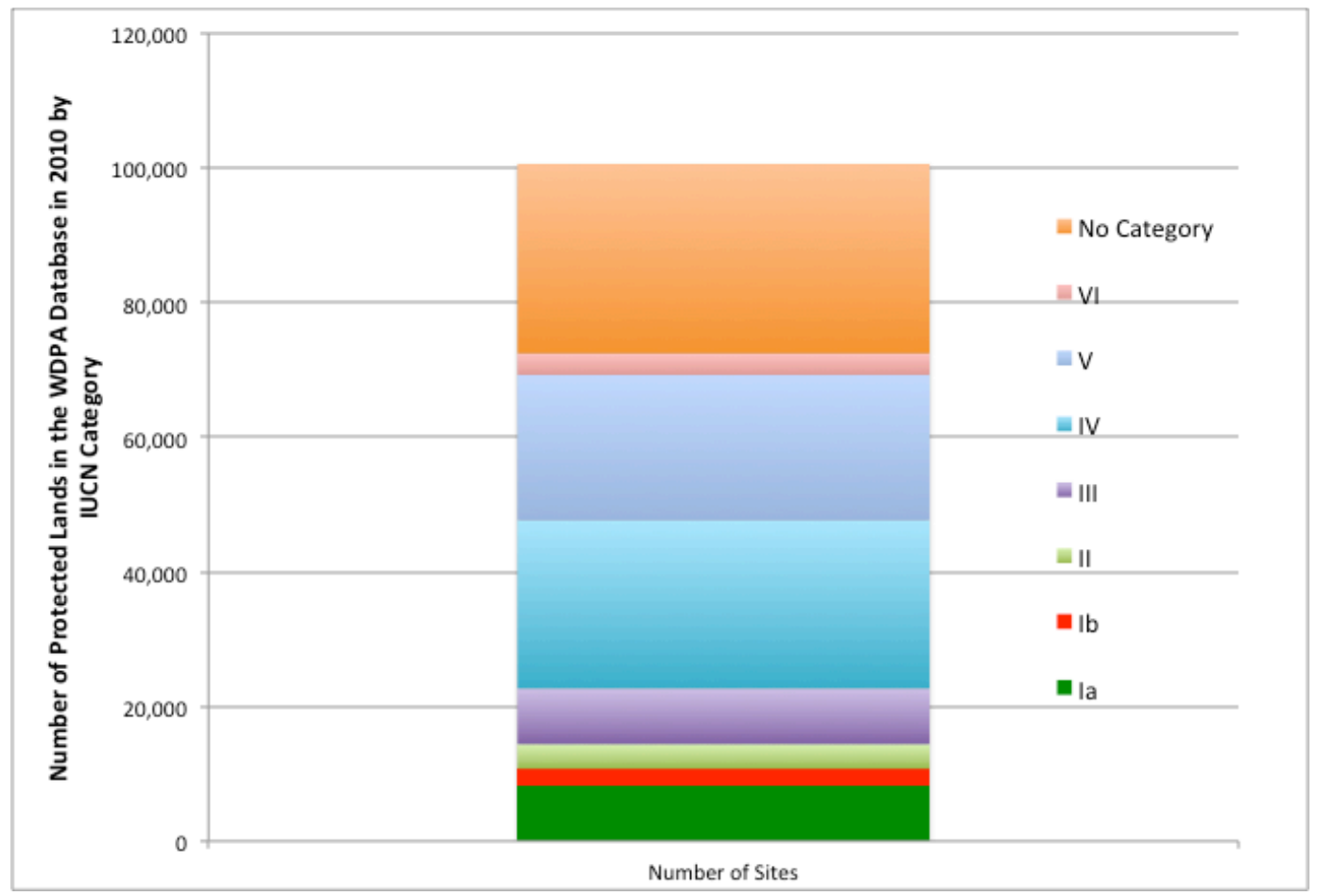

Figure 4 Number of Protected Land Sites Disaggregated by IUCN Category for 2010 (IUCN and UNEP-WCMC, 2010) 
Table 1 Name, Definition and Explanatory Text for each IUCN Protected Land Category

\begin{tabular}{|c|c|c|c|}
\hline $\begin{array}{l}\text { IUCN } \\
\text { Category }\end{array}$ & $\begin{array}{l}\text { Name (Dudley and } \\
\text { Stolton, 2008) }\end{array}$ & $\begin{array}{l}\text { Definition (Dudley and } \\
\text { Stolton, 2008) }\end{array}$ & Additional Information \\
\hline Ia & $\begin{array}{l}\text { Strict Nature Reserve: } \\
\text { protected area managed } \\
\text { mainly for science }\end{array}$ & $\begin{array}{l}\text { Area of land and/or sea } \\
\text { possessing some } \\
\text { outstanding or } \\
\text { representative ecosystems, } \\
\text { geological or physiological } \\
\text { features and/or species, } \\
\text { available primarily for } \\
\text { scientific research and/or } \\
\text { environmental monitoring. }\end{array}$ & $\begin{array}{l}\text { Category 1a lands are the } \\
\text { only ones that explicitly does } \\
\text { not envision some level of } \\
\text { permanent human presence } \\
\text { (Bishop et al., 2004) and } \\
\text { these 1a lands have the most } \\
\text { stringent restrictions on } \\
\text { human visitation (Redford } \\
\text { and Dudley, 2008). }\end{array}$ \\
\hline $1 \mathrm{~b}$ & $\begin{array}{l}\text { Wilderness Area: } \\
\text { protected area managed } \\
\text { mainly for wilderness } \\
\text { protection }\end{array}$ & $\begin{array}{l}\text { Large area of unmodified or } \\
\text { slightly modified land, } \\
\text { and/or sea, retaining its } \\
\text { natural character and } \\
\text { influence, without } \\
\text { permanent or significant } \\
\text { habitation, protected and } \\
\text { managed so as to preserve } \\
\text { its natural condition. }\end{array}$ & $\begin{array}{l}\text { In Kormos' (2008) } \\
\text { description of } 1 \mathrm{~b} \text { lands, it is } \\
\text { clear that the large absolute } \\
\text { size of these } 1 \text { b lands is a key } \\
\text { characteristic that defines Ib } \\
\text { lands from other IUCN } \\
\text { categories. }\end{array}$ \\
\hline II & $\begin{array}{l}\text { National Park: protected } \\
\text { area managed mainly for } \\
\text { ecosystem protection } \\
\text { and recreation }\end{array}$ & $\begin{array}{l}\text { Natural area of land and/or } \\
\text { sea, designated to (a) } \\
\text { protect the ecological } \\
\text { integrity of one or more } \\
\text { ecosystems for present and } \\
\text { future generations, (b) } \\
\text { exclude exploitation or } \\
\text { occupation inimical to the } \\
\text { purposes of designation of } \\
\text { the area and (c) provide a } \\
\text { foundation for spiritual, } \\
\text { scientific, educational, } \\
\text { recreational and visitor } \\
\text { opportunities, all of which } \\
\text { must be environmentally } \\
\text { and culturally compatible. }\end{array}$ & $\begin{array}{l}\text { Redford and Dudley (2008) } \\
\text { note that a significant } \\
\text { practical difference between } \\
\text { Category II and Category Ia } \\
\text { and Ib lands is that "Category } \\
\text { II protected areas usually } \\
\text { combine ecosystem } \\
\text { protection with tourism on a } \\
\text { scale not suitable for } \\
\text { category I." Groves (2008) } \\
\text { notes that Category II, like } \\
\text { Categories Ia and Ib, seeks to } \\
\text { exclude commercial } \\
\text { exploitation as part of the } \\
\text { primary objective." }\end{array}$ \\
\hline
\end{tabular}




\section{Table 1 (continued) Name, Definition and Explanatory Text for each IUCN Protected Land Category}

\begin{tabular}{|c|c|c|c|}
\hline $\begin{array}{l}\text { IUCN } \\
\text { Category }\end{array}$ & $\begin{array}{l}\text { Name (Dudley and } \\
\text { Stolton, 2008) }\end{array}$ & $\begin{array}{l}\text { Definition (Dudley and } \\
\text { Stolton, 2008) }\end{array}$ & Additional Information \\
\hline III & $\begin{array}{l}\text { Natural Monument: } \\
\text { protected area managed } \\
\text { mainly for conservation } \\
\text { of specific natural } \\
\text { features }\end{array}$ & $\begin{array}{l}\text { Area containing one or } \\
\text { more, specific natural or } \\
\text { natural/cultural features, } \\
\text { which are of outstanding or } \\
\text { unique value because of } \\
\text { inherent rarity, } \\
\text { representative or aesthetic } \\
\text { qualities or cultural } \\
\text { significance. }\end{array}$ & $\begin{array}{l}\text { Redford and Dudley (2008) } \\
\text { explain what makes this class } \\
\text { of Protected Lands unique by } \\
\text { noting "Category III } \\
\text { protected areas are generally } \\
\text { centered on a particular } \\
\text { natural monument, so that } \\
\text { the primary focus of } \\
\text { management is on } \\
\text { maintaining this feature, } \\
\text { whereas objectives of Ia [as } \\
\text { well as Ib and II] are } \\
\text { generally aimed at a whole } \\
\text { ecosystem." Dudley (2008b) } \\
\text { notes that Category III lands } \\
\text { could have been Category II } \\
\text { lands but they were simply to } \\
\text { small to support the } \\
\text { ecosystem protections } \\
\text { envisioned in the Category II } \\
\text { lands. }\end{array}$ \\
\hline IV & $\begin{array}{l}\text { Habitat/Species } \\
\text { Management Area: } \\
\text { protected area managed } \\
\text { mainly for conservation } \\
\text { through management } \\
\text { intervention }\end{array}$ & $\begin{array}{l}\text { Area of land and/or sea } \\
\text { subject to active } \\
\text { intervention for } \\
\text { management purposes so as } \\
\text { to ensure the maintenance } \\
\text { of habitats and/or to meet } \\
\text { the requirements of specific } \\
\text { species. }\end{array}$ & $\begin{array}{l}\text { Category IV protected areas } \\
\text { "usually play an important } \\
\text { role in the protection and } \\
\text { survival of [1] one or more } \\
\text { species of nationally or } \\
\text { locally-important flora; [2] } \\
\text { one or more species of } \\
\text { resident or migratory fauna; } \\
\text { and/or [3] their habitats... } \\
\text { [however] because Category } \\
\text { IV protected areas only } \\
\text { include part of an ecosystem, } \\
\text { there is likelihood that it may } \\
\text { not be self-sustaining and } \\
\text { require active management } \\
\text { intervention to ensure the } \\
\text { survival of specific habitats } \\
\text { and/or to meet the } \\
\text { requirements of particular } \\
\text { species."(Dudley and Borrini- } \\
\text { Feyerabend, 2008). }\end{array}$ \\
\hline
\end{tabular}




\section{Table 1 (continued) Name, Definition and Explanatory Text for each IUCN Protected Land Category}

\begin{tabular}{|c|c|c|c|}
\hline $\begin{array}{l}\text { IUCN } \\
\text { Category }\end{array}$ & $\begin{array}{l}\text { Name (Dudley and } \\
\text { Stolton, 2008) }\end{array}$ & $\begin{array}{l}\text { Definition (Dudley and } \\
\text { Stolton, 2008) }\end{array}$ & Additional Information \\
\hline V & $\begin{array}{l}\text { Protected } \\
\text { Landscape/Seascape: } \\
\text { protected area managed } \\
\text { mainly for landscape/ } \\
\text { seascape } \\
\text { conservation and } \\
\text { recreation }\end{array}$ & $\begin{array}{l}\text { Area of land, with coast and } \\
\text { sea as appropriate, where } \\
\text { the interaction of people and } \\
\text { nature over time has } \\
\text { produced an area of distinct } \\
\text { character with significant } \\
\text { aesthetic, ecological and/or } \\
\text { cultural value, and often } \\
\text { with high biological } \\
\text { diversity. Safeguarding the } \\
\text { integrity of this traditional } \\
\text { interaction is vital to the } \\
\text { protection, maintenance and } \\
\text { evolution of such an area. }\end{array}$ & $\begin{array}{l}\text { The active intervention of } \\
\text { humans in maintaining these } \\
\text { sites is a defining feature for } \\
\text { many lands in this category. } \\
\text { For example in Ecuador, } \\
\text { "Most plants and animal } \\
\text { species of the Páramos are } \\
\text { pyrophytic and serotonic, } \\
\text { requiring the continual } \\
\text { human driver of burning for } \\
\text { their existence" (Mallarach et } \\
\text { al., 2008). }\end{array}$ \\
\hline VI & $\begin{array}{l}\text { Managed Resource } \\
\text { Protected Area: } \\
\text { protected area managed } \\
\text { mainly for the } \\
\text { sustainable } \\
\text { use of natural } \\
\text { ecosystems }\end{array}$ & $\begin{array}{l}\text { Area containing } \\
\text { predominantly unmodified } \\
\text { natural systems, managed to } \\
\text { ensure long-term protection } \\
\text { and maintenance of } \\
\text { biological diversity, while } \\
\text { providing at the same time a } \\
\text { sustainable flow of natural } \\
\text { products and services to } \\
\text { meet community needs. }\end{array}$ & $\begin{array}{l}\text { Significant growth in } \\
\text { Category VI lands began in } \\
\text { the early 2000s. According } \\
\text { to Phillips (2008), Category } \\
\text { VI lands are designed to } \\
\text { "recognized the important } \\
\text { role protected areas play in } \\
\text { the sustainable livelihoods of } \\
\text { local people" but that there } \\
\text { are limits to the extent of } \\
\text { human modification that are } \\
\text { consistent with even this } \\
\text { category of lands and } \\
\text { therefore for example "large } \\
\text { commercial plantations" and } \\
\text { "large commercially worked } \\
\text { forests" would be are } \\
\text { excluded from this category. }\end{array}$ \\
\hline
\end{tabular}

\section{Three Levels of Protected Lands in GCAM 3.0}

Three levels of protected lands will be represented within GCAM3.0 and therefore for all intents and purposes not available for human modification, particularly with regard to agriculture, forestry, wind and solar energy production and other landintensive anthropogenic changes. GCAM 3.0 does not account for land devoted to coal, oil and natural gas production, nuclear power generation, carbon dioxide capture and geologic storage and a number of other energy and economic processes at a high degree of spatial resolution. Therefore, in a strict sense these three protected lands categories do not impinge upon the functioning of these aspects of the model. 
Text Box 2: The Special Case of Antarctica in the Accounting of Protected Lands

For all practical purposes, all of Antarctica is a protected land for the purposes of the IUCN/WDPA (see for example page 31 Chape et al., 2003 which explicitly addresses this issue) as well as for the GCAM 3.0. The WDPA lists only 21 terrestrial protected areas in Antarctica, all of which are in IUCN Category 1a. These 21 protected areas encompass approximately $2000 \mathrm{~km}^{2}$ (IUCN and UNEP-WCMC, 2010), which is only $0.02 \%$ of the total land area of Antarctica of 13.2 million $\mathrm{km}^{2}$ (Wolfram|Alpha Knowledgebase, 2012 date accessed March $20,2012)$. Antarctica is a uniquely protected territory because of The Antarctica Treaty, which declares the continent to be a scientific preserve where only peaceful / nonmilitary activities are allowed (U.S. State Department, 2001).

\section{GCAM de minimus Protected Lands Scenario}

In this scenario, which provides strict protection for the smallest amount of lands of the three GCAM 3.0 Protected Lands scenarios, approximately 3.5\% of lands are effectively off-limits. The land categories that are contained within this scenario include IUCN categories Ia, Ib, II, and III. Added to this scenario are also lands that have been designated as World Heritage Sites, Ramsar Wetlands of International Importance, and United Nations Educational, Scientific and Cultural Organization (UNESCO) Man-Biosphere Programme lands if those lands are not already covered under IUCN I, II, and III. ${ }^{6}$ The listing of (natural) World Heritage Sites, international Biosphere Reserves ${ }^{7}$, and Wetlands of International Importance as a part of but separate from (i.e., in their own special category) has been a part of the body of work and international agreements that led to today's WDPA/IUCN system since the early 1970s (Bishop et al., 2004). The lands in the de minimus protected land scenario total 5.0 million $\mathrm{km}^{2}$ (IUCN and UNEP-WCMC, 2010)

The core defining feature of all of the lands covered in this de minimus Protected Lands Scenario is that they are lands that have been officially assigned to the most restrictive IUCN categories (I, II, and III) or have been declared by national and multinational governmental bodies to be extremely valuable ecological or historical lands and have been accorded special protections. "Iconic examples" of the kinds of

${ }^{6}$ Descriptions of the degree of overlap and consistency between the standard IUCN categories and these three additional categories of protected lands which are included in the GCAM 3.0 de minimus Protected Lands Scenario can be found in (Patry, 2008; Ramsar Secretariat, 2008; Verschuuren et al., 2008).

${ }^{7}$ Many of the lands listed in this early compilation of Biosphere Reserves would officially become part of the UNESCO Man and Biosphere (MAB) Program in the mid 1990s once that program was formally adopted (IUCN, 1998). 
lands that are covered in this GCAM de minimus Protected Lands scenario are listed in Table 2.

Table 2: Categories and Examples of Protected Lands in GCAM 3.0 de minimus Protected Lands Scenario

\begin{tabular}{|l|l|}
\hline $\begin{array}{l}\text { Protected } \\
\text { Land Category }\end{array}$ & $\begin{array}{l}\text { Examples (reference is IUCN and UNEP-WCMC, 2010 unless } \\
\text { otherwise noted) }\end{array}$ \\
\hline IUCN-Ia & $\begin{array}{l}\text { The Taylor Rookery, Mac. Robertson Land in Antarctica, which is } \\
\text { home to the largest colony of Emperor Penguins on land (NSF, } \\
\text { 2001). }\end{array}$ \\
\hline IUCN-Ib & $\begin{array}{l}\text { The Gorna Topchia Strict Nature Preserve in Bulgaria, an ecologically } \\
\text { diverse area that is home to many endangered species. }\end{array}$ \\
\hline IUCN-II & Blue Mountain National Park outside of Sydney Australia. \\
\hline IUCN-III & $\begin{array}{l}\text { Palenque National Park in southern Mexico, the site of an ancient } \\
\text { Mayan city-state (17km²); } \\
\text { Thaddeus Kosciuszko National Historic Site, a single historic home in } \\
\text { downtown Philadelphia } \\
\text { Victoria Falls Natural Monument in Zambia (19km²); } \\
\text { The Wang Pong Nature Reserve "no hunting area" in Thailand (km²). }\end{array}$ \\
\hline $\begin{array}{l}\text { UNESCO Man- } \\
\text { Biospehere } \\
\text { Program }\end{array}$ & $\begin{array}{l}\text { Yellowstone National Park in the U.S } \\
\text { Oasis De Sud Morocain (70,000 km2) in eastern Morocco that is } \\
\text { home to more than 1,000,000 people as well as a large number of } \\
\text { species and number of bioclimatic regions (UNESCO, 2011) }\end{array}$ \\
\hline $\begin{array}{l}\text { Ramsar } \\
\text { International } \\
\text { Importance }\end{array}$ & $\begin{array}{l}\text { The Whooping Crane Summer Range, an area of approximately } \\
\text { Sito } \\
\text { Northwest Territories in Canada }\end{array}$ \\
\hline
\end{tabular}

${ }^{8}$ According to Bishop et al., (2004), it is generally accepted that Yellowstone National Park (established in 1872) is "the first 'modern' national park." 
While this set of lands represents a de minimus set of Protected Lands for GCAM 3.0, that should not be interpreted as a judgment on our part as to how narrowly humanity might want to define Protected Lands at some point in the future. Ultimately what is the "right" or "appropriate" level" of Protected Lands is a highly context-specific and normative question. The "iconic examples" in Table 2 are precisely that. They are examples. As a practical matter, some of the lands in this de minimus Protected Lands Scenario are not "protected" in the manner suggested by these "iconic examples." As Dudley (2008a) notes "in practice some areas - e.g. a proportion of Ramsar sites and many forest reserves - are included in the WDPA ...without being protected areas" and therefore even within this de minimus Protected Land Scenario there are lands that actively utilized and managed for reasons that extend beyond strict conservation.

\section{GCAM Core Protected Lands Scenario}

This intermediate scenario in terms of land protection encompasses all the lands covered in the GCAM de minimus Protected Lands Scenario defined above and also includes lands included in IUCN Category IV. The addition of Category IV lands brings the total amount of land under protection to 7.20 million $\mathrm{km}^{2}$ or just slightly more than $5.0 \%$ of the Earth's lands.

Category IV lands can be seen as a continuation and natural progression from Category I, II, and III lands. On the other hand, and as will be explained below in greater detail, Category IV are in many ways distinct from Category V and VI lands; therefore, Category IV lands are a useful transition from strictly managed "wild" lands to much more intensively managed landscapes. Category IV lands are considered as a boundary between the de minimus Protected Lands Scenario and the Expanded Protected Lands Scenario. Table 3 lists examples of Category IV lands.

\section{Table 3 Examples of Category IV Protected Lands in GCAM 3.0 Core Protected Lands Scenario}

\begin{tabular}{|l|l|}
\hline $\begin{array}{l}\text { Protected Land } \\
\text { Category }\end{array}$ & $\begin{array}{l}\text { Examples (reference is IUCN and UNEP-WCMC, 2010 unless } \\
\text { otherwise noted) }\end{array}$ \\
\hline IUCN-IV & $\begin{array}{l}\text { The Analamerana }\left(420 \mathrm{~km}^{2}\right) \text { and Forêt d'Ambre }\left(30 \mathrm{~km}^{2}\right) \text { Special } \\
\text { Preserves in Madagascar designed to protect fragments of } \\
\text { rainforest to protect threatened lemur species (Andrainarivo et al., } \\
\text { 2008; Dudley and Borrini-Feyerabend, 2008); }\end{array}$ \\
& $\begin{array}{l}\text { The Shengjin Hu Wildfowl Sanctuary (334km2), a protected wildlife } \\
\text { refuge for a number of threatened, endangered and critically } \\
\text { endangered water (BirdLife International, 2012) }\end{array}$ \\
\hline
\end{tabular}


In the early 2000s, some environmental NGOs proposed that all extractive industrial activity should be prohibited from IUCN Categories I, II, III, and IV (Dudley, 2008a; Kapila, 2004; Phillips, 2008). This call for the banning of mining and oil and gas production from these categories of protected lands was originally codified as a nonbinding resolution made in 2000 the $2^{\text {nd }}$ IUCN World Conservation Congress (Amman, Jordan) and is often known as the "Amman Recommendation 2.82" (RAMSAR, 2003). While this "Amman Recommendation 2.82" was never put into practice (i.e., never codified in national laws or in any international treaties), it serves as a useful boundary as it is clear from much of the literature on Protected Lands published in the 2000s that there is a sense that IUCN Categories I, II, III, IV best represent "wild areas" 9 and as such should be the focus of international conservation / protection efforts.

Miller (2008) elaborates on the tension that exists between "wild" or "natural" areas and areas that have been or are being significantly altered by humanity when one moves beyond IUCN Categories I, II, and III.

"The assumption was that, overall, conservation policy would ensure that the area and its natural capital remain in their natural, wild form. In cases where sites important for biodiversity values had been degraded, conservation policy would call for their restoration.... Thus, for example, harvesting of timber might be incompatible with the maintenance of the area's biological diversity, or with human visitation. Alternatively, under careful management, the goal of providing fresh water from an area's watersheds could be compatible with recreation, timber harvesting, and certain levels of human settlement. Furthermore, some multipurpose reserves can retain and maintain certain levels or components of biodiversity while supporting human settlement and use; this is of particular relevance where the protection of particular species of high value are considered to be compatible with human communities and their activities on the land."

\section{GCAM Expanded Protected Lands Scenario}

This scenario builds upon the previous two by adding IUCN Category V and VI lands. The addition of Category V and VI lands brings the total amount of land under protection to 11.8 million $\mathrm{km}^{2}$ or just slightly more than $8.2 \%$ of the Earth's lands. Table 4 lists examples of the types of lands covered by these categories.

\footnotetext{
${ }^{9}$ Rose (2008) describes in great detail how culturally loaded the concept of "wild lands" or "wilderness" can be and how it is not a terribly rigorous technical term given that aboriginal people have interacted and shaped lands for millennia or centuries before "settlers" discovered these lands and declared parts of them to be "wild."
} 
Table 4 Examples of Categories V and VI Protected Lands in GCAM 3.0 Expanded Protected Lands Scenario

\begin{tabular}{|c|c|}
\hline $\begin{array}{l}\text { Protected Land } \\
\text { Category }\end{array}$ & $\begin{array}{l}\text { Examples (reference is IUCN and UNEP-WCMC, } 2010 \text { unless } \\
\text { otherwise noted) }\end{array}$ \\
\hline IUCN-V & $\begin{array}{l}\text { Certain aspects of the Chugach National Forest in Alaska have } \\
\text { restrictions on human use as these habitats are still recovering } \\
\text { from the ecological devastation brought on by the Exxon Valdez Oil } \\
\text { Spill in the Spring of } 1989 \text { (IUCN and UNEP-WCMC, 2010). } \\
\text { The Yakima Sportsman State Park in Washington state (100km²) is } \\
\text { an irrigated camping park on the floodplain of the Yakima River in } \\
\text { an "an otherwise desert region" (IUCN and UNEP-WCMC, 2010). }\end{array}$ \\
\hline IUCN-VI & $\begin{array}{l}\text { The Península De Valdés Integral Objective Touristic Nature } \\
\text { Reserve along the Atlantic Coast of Argentina }\left(3,600 \mathrm{~km}^{2}\right) \text { (Wood, } \\
\text { 2007). According to Party (2008), more than half of the land in this } \\
\text { nature reserve is owned by private land owners. Tourism and the } \\
\text { active cooperation of these private landowners is an indispensible } \\
\text { aspect of protecting the critical habitats contained within this } \\
\text { nature reserve. The importance of this as a key habitat led to these } \\
\text { lands being declared a World Heritage Site in } 1999 \text { (IUCN and } \\
\text { UNEP-WCMC, 2010). } \\
\text { The Iowa Waterfowl Production Areas (more than } 100 \mathrm{~km}^{2} \text { ). } \\
\text { There are } 75 \text { Waterfoul Production areas in } 35 \text { counties across the } \\
\text { State of Iowa, whose purpose is to provide habitat for migrating } \\
\text { and breeding waterfowl. "When these areas are first acquired, they } \\
\text { usually consist of cropped fields and drained wetlands. Therefore, } \\
\text { extensive manipulation is required to meet management goals. } \\
\text { Drained wetlands are restored by plugging ditches or building } \\
\text { small water control structures. On the uplands, native grasses, } \\
\text { legumes, and introduced grasses are seeded to provide dense } \\
\text { nesting cover for ducks and other wildlife. Native grasses may be } \\
\text { managed by prescribed burning, haying or grazing" (FWS, 2012). }\end{array}$ \\
\hline
\end{tabular}

In addition to the forgoing discussion about whether Category V and VI lands are really deserving of the status of WDPA "Protected Lands," Dudley (2008a) brings forward another crucial distinction between the most protected lands and the Category V and VI lands when he writes

"IUCN says that all six categories are equally important and this was supported by a resolution at the last World Conservation Congress. But it is important to define what "equal" means here. The social and economic costs of establishing a category I or II protected area - in terms of lost living and agricultural space, 
for instance - are higher than the costs of establishing a category $\mathrm{V}$ area where permanent settlements remain and life often carries on much as usual."

Harmon (2008) goes on to stress that the "protection and maintenance of biological diversity" contained in the IUCN definition of protected lands is the primary determinant of whether a land should be defined as protected. He notes that this would "rightly, exclude" lands such as national historical sites or a grazing allotment on federally owned lands from being described as "protected." Harmon also suggests that consideration should be given to establishing a specific numeric threshold - he suggests 50\%-- of land that is principally used for the "protection and maintenance of biological diversity" for IUCN Category V and Category VI lands or they should be removed from the list of protected lands. On the other hand, Mallarach et al. (2008) argue that "In many geographies, human dominated landscapes are in fact the only option to conserve certain aspects of biodiversity, including "wild" biodiversity, because in many parts of the world virtually all areas are already heavily influenced by humans.... the most biodiverse countries of Europe are in the Mediterranean, where worked landscapes have dominated for two to eight millennia, from the coastal areas to the highest mountains."

Mallarach et al. (2008) write that other scholars have attributed the recent growth in Category V and VI lands is likely driven by political expediency arising from the Convention on Biological Diversity's request that all parties to that agreement are asked to conserve a minimum of $10 \%$ of their area as protected lands. This has led to lands being listed in Category V and Category VI "with no necessarily added biodiversity value." For GCAM-related purposes of defining different levels of protected lands to include in scenarios, it is particularly important to note that this "is artificially inflating the protected area figures" (Mallarach et al., 2008).

The large number of entries in the WDPA database that have no category assigned to them are not represented in GCAM. It is infeasible for the WDPA or the GCAM modeling group to hand check each of these records to see if they are duplicates with minor changes in spelling of other documented protected areas or if they are lands that some entity believes for whatever reason should be protected. That is, there is no way to understand what these "no category" lands represent in reality and therefore they are excluded from GCAM protected lands scenarios. As the WDPA categorizes these "no category" areas, the GCAM can be updated to reflect this new information. In 2010, these "no category" lands account for 3.6 million $\mathrm{km}^{2}$ (IUCN and UNEP-WCMC, 2010).

Text Box 3 Exclusion of "No Category" Lands Contained in WDPA 


\section{Mapping Protected Land Scenarios to GCAM3.0's AEZ Structure}

As noted by Kyle et al. (2011),

"In the core version of GCAM 3.0, the model data for the agriculture and land use parts of the model is comprised of 151 subregions in terms of land use, based on a division of the extant 18 types of agro-ecological zones (AEZs), which are derived from work performed for the GTAP project ... within each of GCAM's 14 global geo-political regions.... Within each of these 151 subregions, land is categorized into approximately a dozen types based on cover and use.... Three of these types-tundra, desert, and built-up land-are not considered available for any other uses. The remaining land types are all subject to land use change over time according to changes in future profit rates."

These lands are further divided into SAGE land types as first described by Ramankutty and Foley (1999). A fuller description of how the SAGE land types are used within GCAM 3.0 is provided in Kyle et al. (2011).

A three step method has been created by the authors to map Protected Lands to the AEZ and SAGE used within GCAM. First, we built a framework with integration of three datesets of Protected Lands, AEZ, and SAGE. We processed the three input datasets and set them in the framework with same spatial resolution and projection. The spatial resolution of $5 \mathrm{~min}$ is chosen based on SAGE data, the highest spatial resolution among three. With this design we can minimize the information loss in the spatial process. For the Protected Lands in shapefile vector originally, we converted it to raster data in 5 min spatial resolution. For AEZ data in 0.5 degree, we rescaled it to same $5 \mathrm{~min}$ spatial resolution as SAGE data. Second, we performed a spatial calculation with three datasets in the designed framework. We derived the combination of 15 SAGE types and three types of Protected Lands in each 5 min grid cell. Then, we calculated the total area of each combination of SAGE type and Protected Lands in 18 AEZs in each country. To achieve better estimation, the data of land area (with water excluded) in this 5 min resolution was used to calculate the total area of each combination.

Tables 5 and 6 show how the three GCAM 3.0 protected land scenarios play out across the 15 different SAGE Land Types. It is clear that at the aggregate level depicted in Tables 5 and 6 Protected Lands comprise relatively small portions of the total global amount of land in any SAGE category. This is true even in the GCAM 3.0 Expanded Protected Lands Scenario. 
Table 5: Overview of GCAM Protected Land Scenarios across SAGE land types $\left(\mathrm{km}^{2}\right)$

\begin{tabular}{|c|c|c|c|c|c|}
\hline & SAGE Land Type & de minimus & Core & Expanded & Not Protected \\
\hline 15 & Polar Desert, Rock/Ice & 61,667 & 79,697 & 176,697 & $15,924,217$ \\
\hline 14 & Desert & 351,123 & 552,994 & $1,171,995$ & $14,076,377$ \\
\hline 13 & Tundra & 370,337 & 544,163 & $1,362,614$ & $5,399,308$ \\
\hline 12 & Open Shrubland & 485,793 & 616,666 & $1,015,933$ & $10,856,135$ \\
\hline 11 & Dense Shrubland & 152,809 & 182,003 & 401,609 & $5,547,442$ \\
\hline 10 & Grassland, Steppe & 321,453 & 522,481 & 764,647 & $13,418,727$ \\
\hline 9 & Savanna & 864,975 & $1,200,798$ & $1,589,324$ & $17,455,957$ \\
\hline 8 & $\begin{array}{l}\text { Evergreen/Deciduous } \\
\text { Mixed Forest/Woodland }\end{array}$ & 534,810 & 990,241 & $1,270,483$ & $13,388,477$ \\
\hline 7 & $\begin{array}{l}\text { Boreal Deciduous } \\
\text { Forest/Woodland }\end{array}$ & 43,979 & 121,142 & 154,295 & $2,040,361$ \\
\hline 6 & $\begin{array}{l}\text { Boreal Evergreen } \\
\text { Forest/Woodland }\end{array}$ & 318,247 & 493,784 & 554,812 & $5,243,667$ \\
\hline 5 & $\begin{array}{l}\text { Temperate Deciduous } \\
\text { Forest/Woodland }\end{array}$ & 56,835 & 94,808 & 352,211 & $4,441,577$ \\
\hline 4 & $\begin{array}{l}\text { Temperate Needleleaf } \\
\text { Evergreen } \\
\text { Forest/Woodland }\end{array}$ & 91,231 & 141,745 & 207,147 & $3,342,292$ \\
\hline 3 & $\begin{array}{l}\text { Temperate Broadleaf } \\
\text { Evergreen } \\
\text { Forest/Woodland }\end{array}$ & 74,921 & 77,792 & 113,757 & $1,002,549$ \\
\hline 2 & $\begin{array}{l}\text { Tropical Deciduous } \\
\text { Forest/Woodland }\end{array}$ & 159,404 & 255,718 & 339,035 & $5,471,636$ \\
\hline 1 & $\begin{array}{l}\text { Tropical Evergreen } \\
\text { Forest/Woodland }\end{array}$ & $1,159,024$ & $1,324,715$ & $2,317,501$ & $14,290,220$ \\
\hline & Total & $5,046,607$ & $7,198,747$ & $11,792,061$ & $131,898,942$ \\
\hline
\end{tabular}


Table 6: Overview of GCAM Protected Land Scenarios across SAGE land types (percent of SAGE Land Type protected under each scenario)

\begin{tabular}{|c|c|c|c|c|c|}
\hline & Sage Land Type & De minimus & Core & Expanded & Not Protected \\
\hline 15 & Polar Desert, Rock/Ice & $0 \%$ & $0 \%$ & $1 \%$ & $99 \%$ \\
\hline 14 & Desert & $2 \%$ & $4 \%$ & $8 \%$ & $92 \%$ \\
\hline 13 & Tundra & $5 \%$ & $8 \%$ & $20 \%$ & $80 \%$ \\
\hline 12 & Open Shrubland & $4 \%$ & $5 \%$ & $9 \%$ & $91 \%$ \\
\hline 11 & Dense Shrubland & $3 \%$ & $3 \%$ & $7 \%$ & $93 \%$ \\
\hline 10 & Grassland, Steppe & $2 \%$ & $4 \%$ & $5 \%$ & $95 \%$ \\
\hline 9 & Savanna & $5 \%$ & $6 \%$ & $8 \%$ & $92 \%$ \\
\hline 8 & $\begin{array}{l}\text { Evergreen/Deciduous Mixed } \\
\text { Forest/Woodland }\end{array}$ & $4 \%$ & $7 \%$ & $9 \%$ & $91 \%$ \\
\hline 7 & $\begin{array}{l}\text { Boreal Deciduous } \\
\text { Forest/Woodland }\end{array}$ & $2 \%$ & $6 \%$ & $7 \%$ & $93 \%$ \\
\hline 6 & $\begin{array}{l}\text { Boreal Evergreen } \\
\text { Forest/Woodland }\end{array}$ & $5 \%$ & $9 \%$ & $10 \%$ & $90 \%$ \\
\hline 5 & $\begin{array}{l}\text { Temperate Deciduous } \\
\text { Forest/Woodland }\end{array}$ & $1 \%$ & $2 \%$ & $7 \%$ & $93 \%$ \\
\hline 4 & $\begin{array}{l}\text { Temperate Needleleaf } \\
\text { Evergreen Forest/Woodland }\end{array}$ & $3 \%$ & $4 \%$ & $6 \%$ & $94 \%$ \\
\hline 3 & $\begin{array}{l}\text { Temperate Broadleaf Evergreen } \\
\text { Forest/Woodland }\end{array}$ & $7 \%$ & $7 \%$ & $10 \%$ & $90 \%$ \\
\hline 2 & $\begin{array}{l}\text { Tropical Deciduous } \\
\text { Forest/Woodland }\end{array}$ & $3 \%$ & $4 \%$ & $6 \%$ & $94 \%$ \\
\hline 1 & $\begin{array}{l}\text { Tropical Evergreen } \\
\text { Forest/Woodland }\end{array}$ & $7 \%$ & $8 \%$ & $14 \%$ & $86 \%$ \\
\hline & Total & $3.51 \%$ & $5.01 \%$ & $8.21 \%$ & $92 \%$ \\
\hline
\end{tabular}


As demonstrated by the discussion of different IUCN categories, protected lands comprise a wide range of types and management purposes; they also exhibit a wide geographic dispersion and size distribution. Protected lands are unevenly distributed across the globe, and many are small. Examining a crosswalk between AEZs and protected lands illustrates this point.

Most AEZs cross national boundaries and the vast majority of the nations of the world contain more than one AEZ. Thus, when the 151 AEZs are projected on to the 231 nations, 696 "subnational AEZ's" are created. Here we briefly examine how these three GCAM 3.0 Protected Land Scenarios play out at this level of geospatial disaggregation.

In the de minimus Protected Land Scenario, $60 \%$ of the subnational AEZs do not contain any Protected Lands. For the Core Protected Lands Scenario, $52 \%$ of the subnational AEZs do not contain any Protected Lands. And lastly in the Expanded Protected Land Scenario, $43 \%$ of the subnational AEZs do not contain any Protected Lands.

Figure 5 is a box-and-whiskers plot of the subnational AEZs that do contain some level of protected lands within them across these three GCAM 3.0 scenarios (i.e., the subnational AEZs that do not contain any protected lands have been excluded). The percentage of protected lands within these subnational AEZs ranges from $100 \%$ to just a tiny fraction of $1 \%$ and this holds true across all three GCAM 3.0 Protected Land Scenarios, i.e., some subnational AEZs are completely comprised of Protected Lands while other subnational AEZ's have only a very small portion that is classified as protected.

The purple line in Figure 5 shows the average percent of land that is "protected" across the subnational AEZs, which contain Protected Lands and this value ranges from $14 \%$, (de minimus), to 16\% (Core), to 20\% (Expanded) across the three protected land scenarios. The grey boxes show the fraction of protected lands in each of subnational AEZ that falls within the range from the $25^{\text {th }}$ to $75^{\text {th }}$ percentile of all the subnational lands that contain some Protected Lands.

- For the de minimus Protected Land Scenario this range spans $1.7 \%$ to $16.6 \%$ of the subnational AEZs that fall within this category.

- For the Core Protected Land Scenario this range spans 2.5\% to $19.0 \%$ of the subnational AEZs that fall within this category.

- For the de minimus Protected Land Scenario this range spans 3.5\% to $25.1 \%$ of the subnational AEZs that fall within this category. 


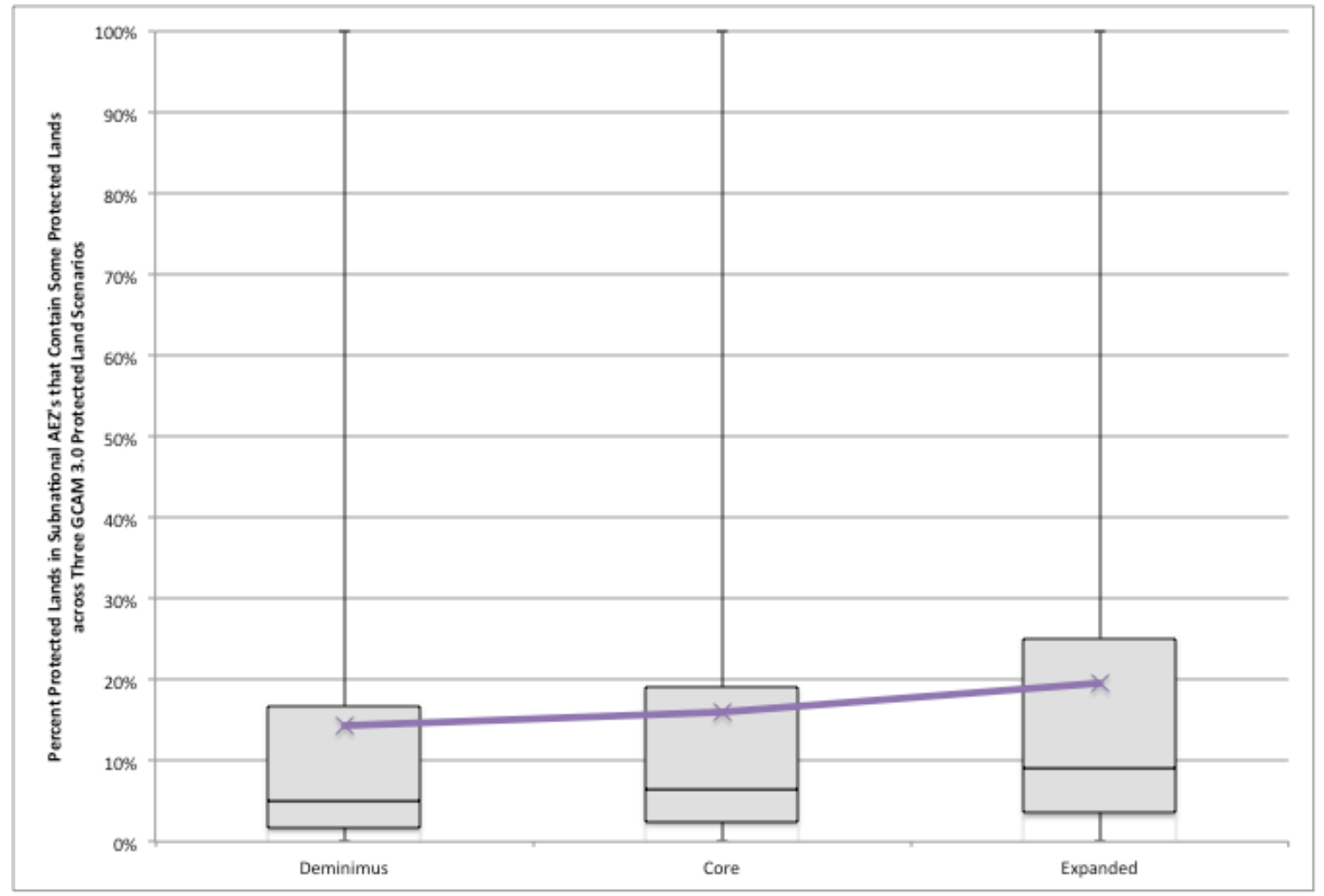

Figure 5 Whisker Plot of Percent of Subnational AEZ that is Protected Lands for those AEZs that Contain Any Protected Lands showing minimum, maximum, average (purple line) and range of 25 th to 75 th percentile

Figure 6 shows the spatial extent and geographic distribution of protected lands across the three GCAM 3.0 Protected Land Scenarios for South America, Southern Africa and Australia.

Lastly Figures 7, 8 and 9 show how the different SAGE Land Types are represented in the total amount of protected lands across the three different GCAM 3.0 Protected Land Scenarios. It is clear that Tropical Evergreen Forests, Woodlands, Savannas and Temperate Broadleaf Evergreen Forest/Woodland account for approximately half of all the protected lands across these three GCAM scenarios. At the other end of the spectrum, areas classified as "Polar Desert, Rock/Ice", Boreal Deciduous Forests/Woodland, Temperate Deciduous Forests/Woodlands account for relatively small aspects of the total amount of Protected Lands across these three scenarios. 


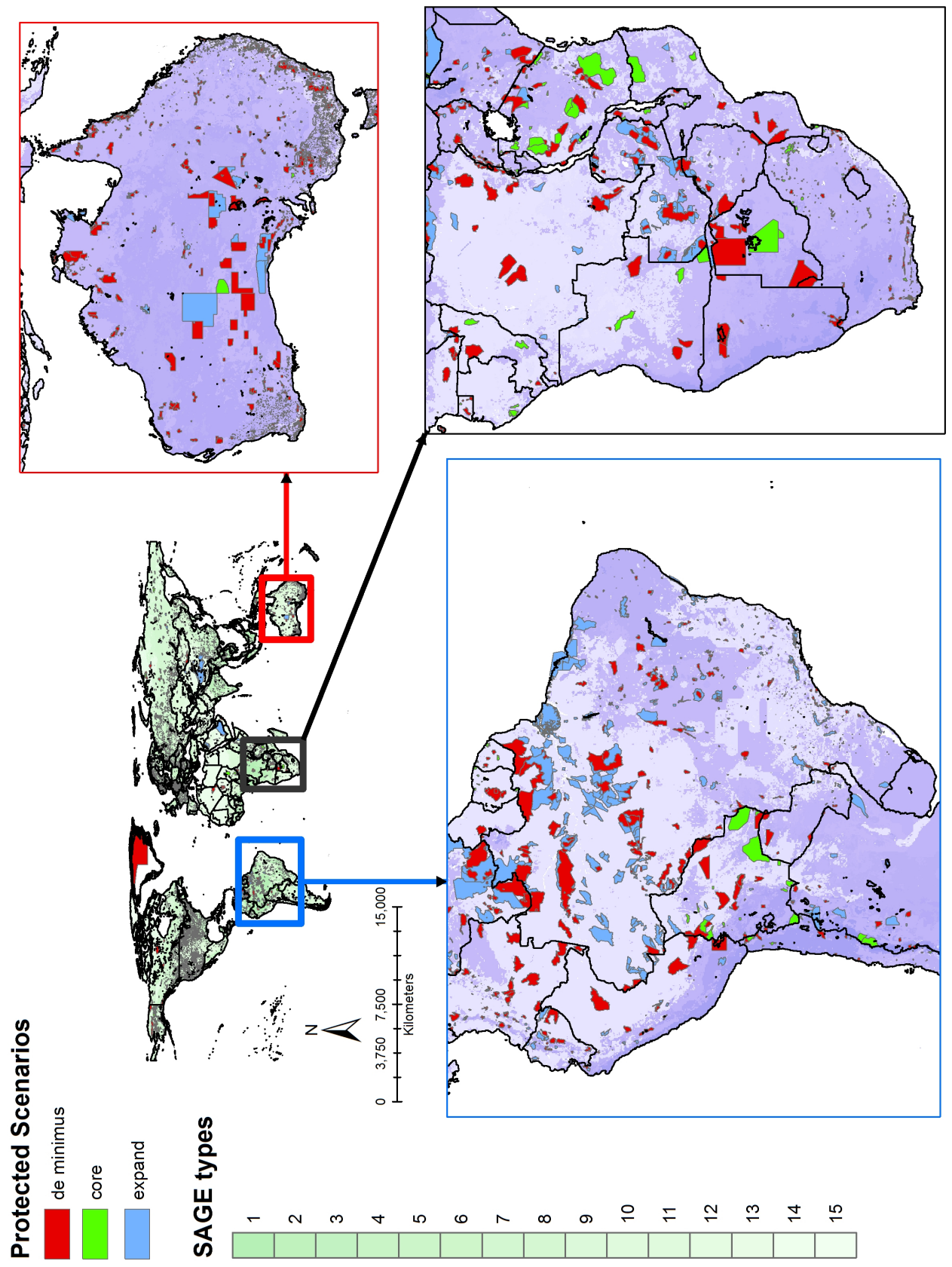

Figure 6 Examples of Protected Lands in South America, Southern Africa, and Australia across the Three GCAM Protected Lands Scenarios 


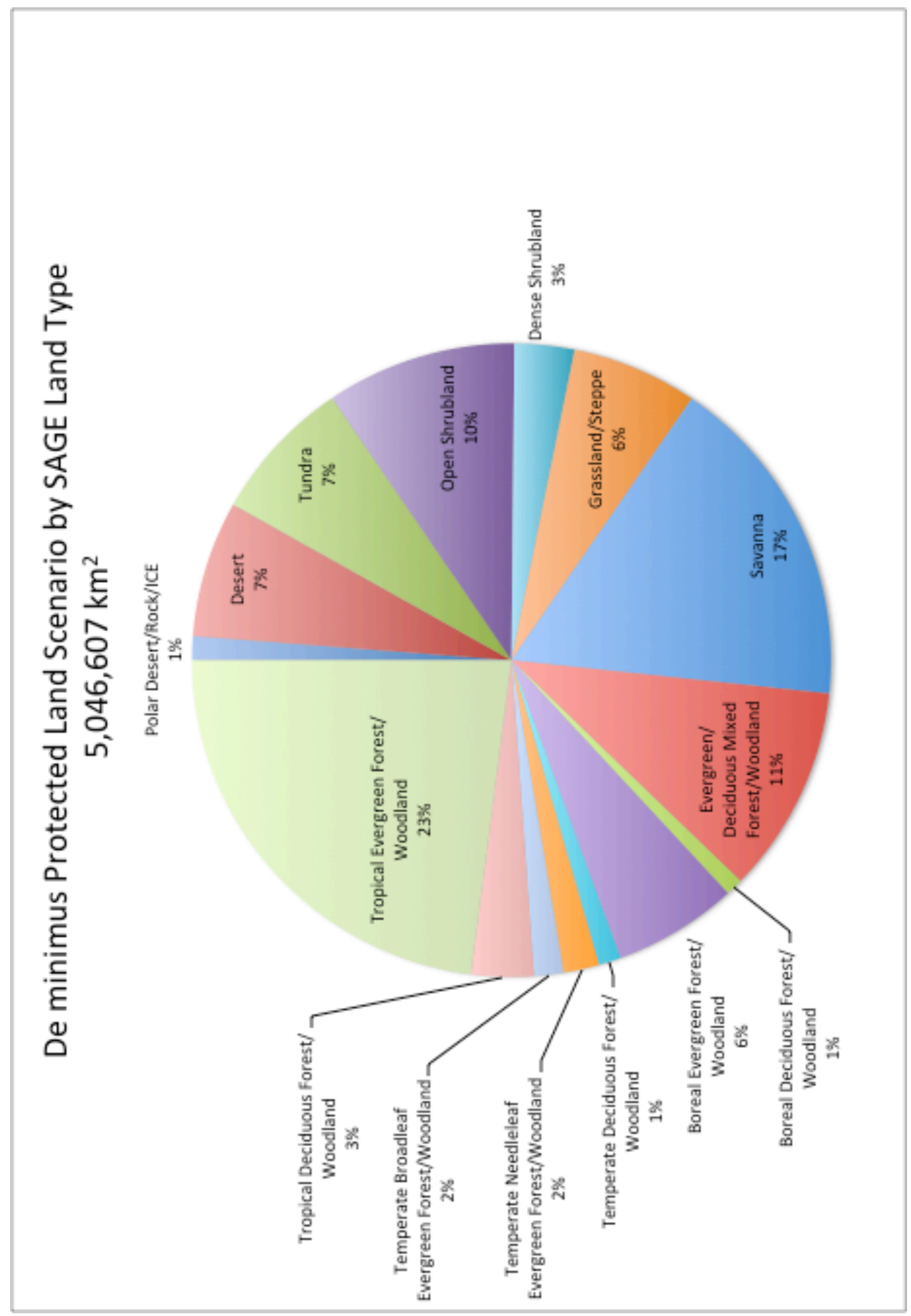

Figure 7 Allocation of de minimus Protected Land Scenario by SAGE Land Type 


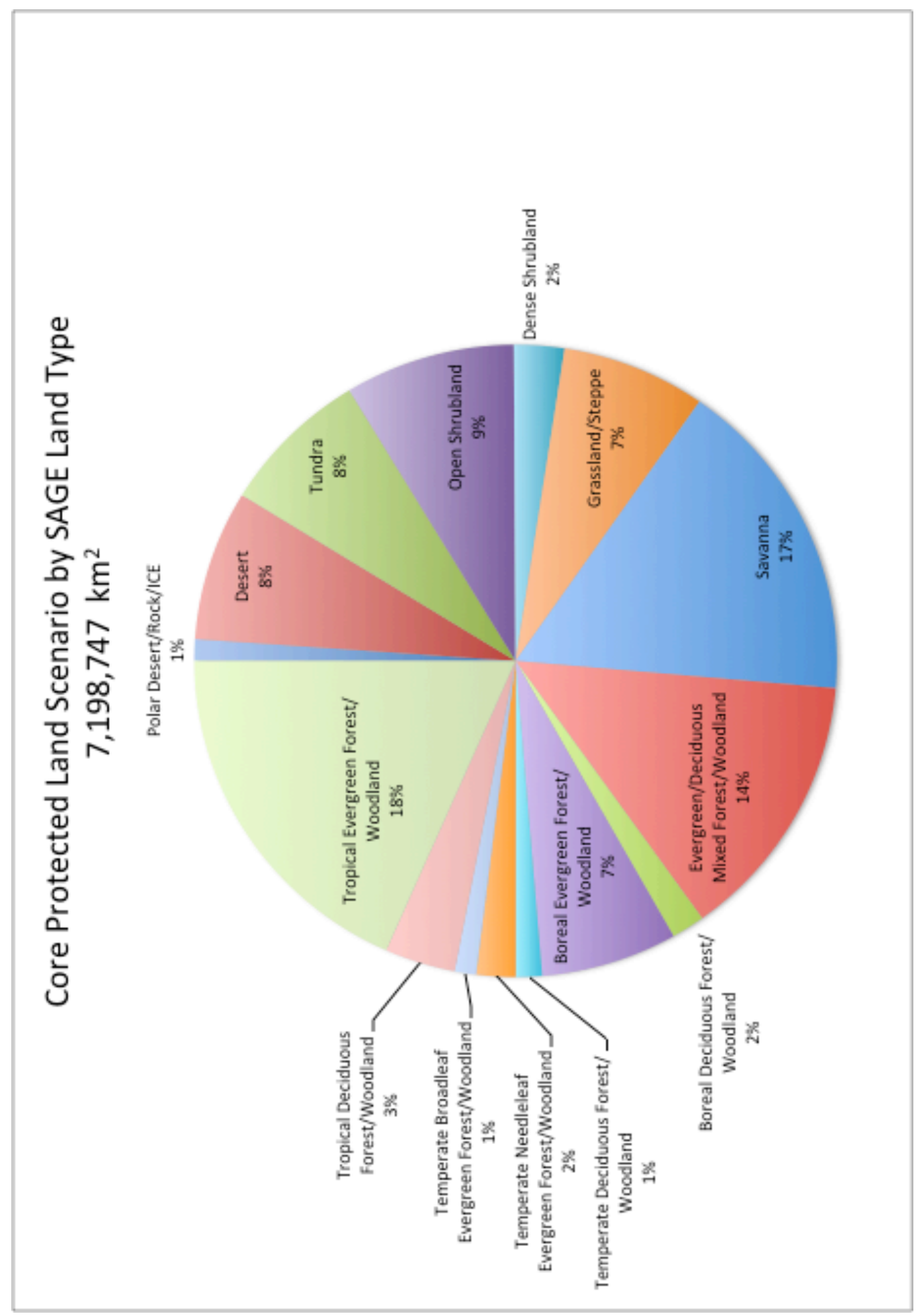

Figure 8 Allocation of Core Protected Land Scenario by Sage Land Type 
Figure 9 Allocation of Expanded Protected Land Scenario by Sage Land Type

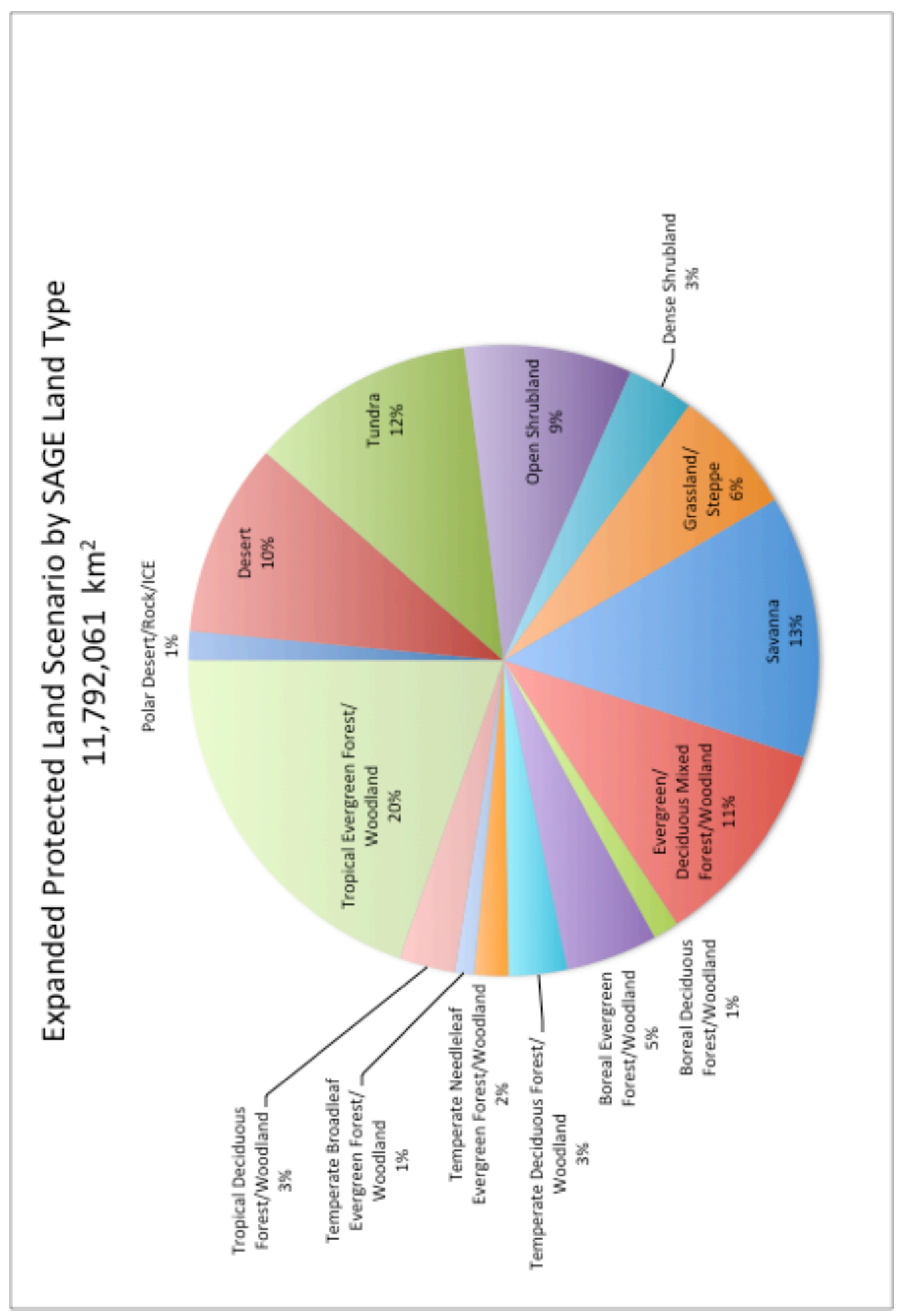




\section{Concluding Summary Point}

In closing, we will repeat Figure 2 below as it provides a useful intellectual framework for summarizing the foregoing analysis. When looking across these three very different GCAM 3.0 Protected Land Scenarios, one can interpret Figure 2 as implying degrees of future fungibility between various classes of Protected Land types. For example, a Category 1a protected land will always be protected across all three scenarios. However, the apparent deep-seated ambivalence within the conservation community as to whether Category V and Category VI are sufficiently "wild" coupled with the fact that significant human activities already take place in these Category V and VI lands suggests that there is some potential that in the (perhaps distant) future society might convert Category V and Category VI lands into non-protected (i.e., "working lands"). Therefore, within GCAM 3.0 these lands will be considered as being available for agriculture, forestry and other human uses when the model is using either the de minimus Protected Land Scenario or the Core Protected Land Scenario.

\author{
IUCN Protected \\ Land Category
}

$\mathrm{Ia} / \mathrm{lb}, \mathrm{II}, \mathrm{III} \quad$ IV $\quad \mathrm{V} / \mathrm{VI}$
Unprotected

Landscapes

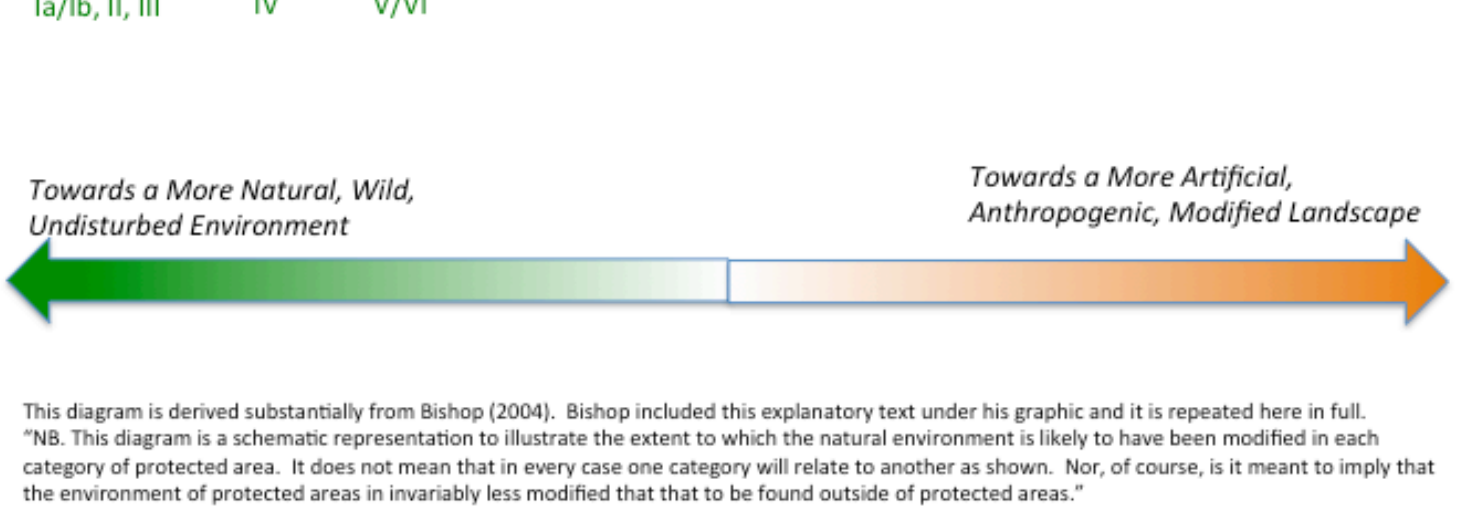

Figure 2 Schematic showing the varying levels of human intervention / modification across protected land categories (adapted from (Phillips, 2004)) 


\section{References}

Andrainarivo, C., Andriaholinirina, V., Feistner, A., Felix, T., Ganzhorn, J., Garbutt, N., Golden, C., Konstant, B., Louis, E., Meyers, D., Mittermeier, R., Perieras, A., Princee, F., Rabarivola, J., Rakotosamimanana, B., Rasamimanana, H., Ratsimbazafy, J., Raveloarinoro, G., Razafimanantsoa, A., Rumpler, Y., Schwitzer, C., Thalmann, U., Wilmé, L., Wright, P., 2008. Eulemur coronatus, The IUCN Red List of Threatened Species. Version 2011.2. IUCN Global Species Programme Red List Unit.

BirdLife International, 2012. Important Bird Areas factsheet: Shengin Hu Nature Reserve, 2012 ed. BirdLife International.

Bishop, K., Dudley, N., Phillips, A., Stolton, S., 2004. Speaking a common language: the uses and performances of the IUCN system of management categories for protected areas. Cardiff University ; IUCN, Protected Areas Programme ; UNEP-WCMC ; WWF ; Conservation International ; Shell Corporation ; BP plc ; International Council on Mining and Metals, Cardiff, p. 119.

Chape, S., Blyth, S., Fish, L., Fox, P., Spalding, M., 2003. 2003 United Nations List of Protected Areas. IUCN, Gland, Switzerland and Cambridge, UK, p. 44.

CIESIN, 2005. Gridded Population of the World (GPW), Version 3. Center for International Earth Science Information Network (CIESIN), Columbia University and Centro Internacional de Agricultura Tropical (CIAT) Palisades, NY: CIESIN, Columbia University.

Dudley, N., 2008a. 3.1. Clarifying the IUCN definition of a protected area, in: Dudley, N., Stolton, S. (Eds.), Defining Protected Areas an International Conference in Almeria, Spain, May 2007. IUCN, Almeria, Spain, May 2007, p. 221.

Dudley, N., 2008b. 4.4. Category III, in: Dudley, N., Stolton, S. (Eds.), Defining Protected Areas an International Conference in Almeria, Spain, May 2007. IUCN, Almeria, Spain, May 2007, p. 221.

Dudley, N., Borrini-Feyerabend, G., 2008. 4.5. Category IV, in: Dudley, N., Stolton, S. (Eds.), Defining Protected Areas an International Conference in Almeria, Spain, May 2007. IUCN, Almeria, Spain, May 2007, p. 221.

Dudley, N., Stolton, S., 2008. Introduction, in: Dudley, N., Stolton, S. (Eds.), Defining Protected Areas an International Conference in Almeria, Spain, May 2007. IUCN, Almeria, Spain, May 2007, p. 221.

FWS, 2012. Iowa Wetland Management District. US Fish and Wildlife Service.

Groves, C., 2008. 4.3. Category II, in: Dudley, N., Stolton, S. (Eds.), Defining Protected Areas an International Conference in Almeria, Spain, May 2007. IUCN, Almeria, Spain, May 2007, p. 221.

Harmon, D., 2008. 3.2. What does IUCN's protected area definition actually mean?, in: Dudley, N., Stolton, S. (Eds.), Defining Protected Areas an International Conference in Almeria, Spain, May 2007. IUCN, Almeria, Spain, May 2007, p. 221.

IUCN, 1998. 1997 United Nations List of Protected Areas. IUCN, Gland, Switzerland and Cambridge, UK, p. 412. 
IUCN, UNEP-WCMC, 2012a. Growth in global extent of protected areas (1911-2011), The World Database on Protected Areas (WDPA), February 2012 ed. United Nations Environment Program, World Conservation Monitoring Centre.

IUCN, UNEP-WCMC, 2012b. Growth in global number of protected areas (19112011), The World Database on Protected Areas (WDPA), February 2012 ed. United Nations Environment Program, World Conservation Monitoring Centre.

IUCN and UNEP-WCMC, 2010. The World Database on Protected Areas (WDPA). Cambridge, UKUNEP- WCMC.

Kapila, S., 2004. Shell's perspective on the IUCN protected areas management category system, in: Bishop, K., Dudley, N., Phillips, A., Stolton, S. (Eds.), Parks, The International Journal for Protected Area Managers: Special Issue on Protected Area Categories. International Conservation Union Network, Gland, Switzerland, pp. 46-50.

Kormos, C., 2008. 4.2. Category Ib, in: Dudley, N., Stolton, S. (Eds.), Defining Protected Areas an International Conference in Almeria, Spain, May 2007. IUCN, Almeria, Spain, May 2007, p. 221.

Kyle, G., Luckow, p., Calvin, K.V., Emanuel, W., Nathan, M., Zhou, Y., 2011. GCAM 3.0 Agriculture and Land Use: Data Sources and Methods. Joint Global Change Research Institutue, Pacific Northwest National Laboratory, College Park, MD, p. 58.

Luckow, P., Wise, M.A., Dooley, J.J., Kim, S.H., 2010. Large-scale utilization of biomass energy and carbon dioxide capture and storage in the transport and electricity sectors under stringent $\mathrm{CO} 2$ concentration limit scenarios. International Journal of Greenhouse Gas Control 4, 865-877.

Mallarach, J.M., Morrison, J., Kothari, A., Sarmiento, F., Atauri, J.-A., Wishitemi, B., 2008. 3.4. In defence of protected landscapes: A reply to some criticisms of category V protected areas and suggestions for improvement, in: Dudley, N., Stolton, S. (Eds.), Defining Protected Areas an International Conference in Almeria, Spain, May 2007. IUCN, Almeria, Spain, May 2007, p. 221.

Miller, K., 2008. 2.2. A commentary on the origins of the category system, in: Dudley, N., Stolton, S. (Eds.), Defining Protected Areas an International Conference in Almeria, Spain, May 2007. IUCN, Almeria, Spain, May 2007, p. 221.

NSF, 2001. Antarctic Conservation Act of 1978 (Public Law 95-541) as amended by Antarctic Science, Tourism, and Conservation Act of 1996 (Public Law 104227). Office of Polar Programs, US National Science Foundation, Arlington, VA.

Patry, M., 2008. 8.2. World Heritage and IUCN categories, in: Dudley, N., Stolton, S. (Eds.), Defining Protected Areas an International Conference in Almeria, Spain, May 2007. IUCN, Almeria, Spain, May 2007, p. 221.

Phillips, A., 2004. The history of the international system of protected area management categories, in: Bishop, K., Dudley, N., Phillips, A., Stolton, S. (Eds.), Parks, The International Journal for Protected Area Managers: Special Issue on Protected Area Categories. International Conservation Union Network, Gland, Switzerland, pp. 4-14. 
Phillips, A., 2008. 2.1. A short history of the international system of protected areas management categories, in: Dudley, N., Stolton, S. (Eds.), Defining Protected Areas an International Conference in Almeria, Spain, May 2007. IUCN, Almeria, Spain, May 2007, p. 221.

Ramankutty, N., Foley, J., 1999. Estimating historical changes in global land cover: croplands from 1700 to 1992. Global Biogeochemical Cycles 13, 997-1027.

RAMSAR, 2003. Ramsar-related Recommendations of the World Parks Congress, Durban, September 2003; Rec 5.28 Protected areas: mining and energy.

Ramsar Secretariat, 2008. 8.1 Wetlands of international importance and the IUCN system of protected area management categories, in: Dudley, N., Stolton, S. (Eds.), Defining Protected Areas an International Conference in Almeria, Spain, May 2007. IUCN, Almeria, Spain, May 2007, p. 221.

Redford, K.H., Dudley, N., 2008. 4.1. Category Ia, in: Dudley, N., Stolton, S. (Eds.), Defining Protected Areas an International Conference in Almeria, Spain, May 2007. IUCN, Almeria, Spain, May 2007, p. 221.

Richards, D., Parsons, E., 2004. International Council on Mining and Metals perspective on the IUCN protected areas management category system, in: Bishop, K., Dudley, N., Phillips, A., Stolton, S. (Eds.), Parks, The International Journal for Protected Area Managers: Special Issue on Protected Area Categories. International Conservation Union Network, Gland, Switzerland, pp. 39-45.

Rose, D.B., 2008. 3.3. What do we mean by wild?, in: Dudley, N., Stolton, S. (Eds.), Defining Protected Areas an International Conference in Almeria, Spain, May 2007. IUCN, Almeria, Spain, May 2007, p. 221.

Thomson, A., Calvin, K., Smith, S., Kyle, G., Volke, A., Patel, P., Delgado-Arias, S., BondLamberty, B., Wise, M., Clarke, L., Edmonds, J., 2011. RCP4.5: a pathway for stabilization of radiative forcing by 2100 . Climatic Change 109, 77-94.

U.S. State Department, 2001. Full Text of "The Antarctic Treaty" as ratified by the U.S. Senate on August 10, 1960 and which went into force on June 23, 1961, in: U.S. State Department (Ed.).

UNEP-WCMC, 2010. Data Standards for the World Database on Protected Areas, in: United Nations Environment Programme World Conservation Monitoring Centre (WCMC) (Ed.), Cambridge, p. 9.

UNESCO, 2011. Oasis Du Sud Marocain, Man-Biosphere Reserves Directory, 10/16/2001 ed. United Nations Educational, Scientific and Cultural Organization.

Verschuuren, B., Mallarach, J.M., Oviedo, G., 2008. 9.4. Sacred sites and protected areas, in: Dudley, N., Stolton, S. (Eds.), Defining Protected Areas an International Conference in Almeria, Spain, May 2007. IUCN, Almeria, Spain, May 2007, p. 221.

Wise, M., Calvin, K., 2011. GCAM 3.0 Agriculture and Land Use: Technical Description of Modeling Approach. Joint Global Change Research Institutue, Pacific Northwest National Laboratory, College Park, MD, p. 51.

Wise, M., Calvin, K., Thomson, A., Clarke, L., Bond-Lamberty, B., Sands, R., Smith, S.J., Janetos, A., Edmonds, J., 2009. Implications of Limiting $\mathrm{CO}_{2}$ Concentrations for Land Use and Energy. Science 324, 1183-1186. 
Wood, L., 2007. MPA Global: A database of the world's marine protected areas, Sea Around Us Project. UNEP-WCMC \& WWF. 